highest temperatures of explosion flames. There is no evidence in these experiments of any real discontinuity between the chemical phenomena of ordinary "inflammation" and those of "detonation." The higher temperatures and more violent conditions in "detonation" are responsible for the more complete breaking down of unsaturated hydrocarbons and a greater "unburning" of steam by carbon, but there is probably no difference as regards the mode in which the hydrocarbon is attacked by the oxygen in the two cases.

Results of Explosion of an Equimolecular Mixture of Ethane and Oxygen under High Pressures.

\begin{tabular}{|c|c|c|c|c|c|c|c|}
\hline & - & Det & $\begin{array}{r}\text { A } \\
\text { onatio } \\
\mathrm{Co}\end{array}$ & $\begin{array}{l}n \text { in Lead } \\
\text { il }\end{array}$ & Explo & sion in & Steel Bomb \\
\hline & $\begin{array}{c}p_{1} \\
p_{2} \\
p_{9} / p_{1}\end{array}$ & & $\begin{array}{r}180 \\
2240 \\
1.9\end{array}$ & mm. & & $\begin{array}{r}25.2 \\
51.7 \\
2.0\end{array}$ & atms. \\
\hline 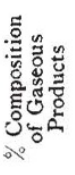 & $\begin{array}{c}\mathrm{CO}_{2} \\
\mathrm{CO} \\
\mathrm{C}_{2} \mathrm{H}_{2} \\
\mathrm{C}_{2} \mathrm{H}_{4} \\
\mathrm{CH}_{4} \\
\mathrm{H}_{2}\end{array}$ & & $\begin{array}{r}\mathbf{1} \cdot 8 \\
39 \cdot 1 \\
0.9 \\
0.5 \\
7 \cdot 7 \\
50.0\end{array}$ & $\left.\begin{array}{l}0 \\
0 \\
0 \\
0 \\
0 \\
0 \\
0 \\
0\end{array}\right\} I^{\prime} 40$ & \} & $\begin{array}{r}2 \cdot 6 \\
37 \cdot 2 \\
n i l \\
7 \cdot 0 \\
52 \cdot 2\end{array}$ & \\
\hline $\begin{array}{l}\text { Origin } \\
\text { Gaseo }\end{array}$ & $\begin{array}{l}\text { mixture. } \\
\text { products }\end{array}$ & $\begin{array}{c}\text { C } \\
\text { I } 186 \\
1151\end{array}$ & $\begin{array}{c}\mathrm{H} \\
1779 \\
1507\end{array}$ & $\begin{array}{c}0 \\
587 \mathrm{~mm} . \\
488,\end{array}$ & $\begin{array}{c}C \\
25 \cdot 35 \\
24 \cdot 50\end{array}$ & $\begin{array}{c}\mathrm{H} \\
3^{8} \cdot 0 \\
34^{\circ} \cdot 6\end{array}$ & $\begin{array}{c}O \\
12.55 \text { atms. } \\
11.05\end{array}$ \\
\hline Diff & nce. . & 35 & 272 & 99 , & 0.85 & 34 & I'5 \\
\hline$\% \mathrm{I}$ & rence. & 3 & 15 & 17 & 34 & 9 & $122^{\circ}$ \\
\hline
\end{tabular}

I therefore believe that, so far as our present knowledge goes, the views I have put forward afford a simple and consistent interpretation of hydrocarbon combustion, whether it be the slow flameless kind discovered by Davy or the more eomplex phenomena of ordinary flames so wonderfully expounded by him, or, finally, the extreme conditions of temperature and pressure characteristic of the explosion wave.

\section{SUPPLEMENTARY LIST OF FORTHCOMING BOOKS OF SCIENCE.}

I $\mathrm{N}$ addition to the books referred to in Nature of last week, the following works are announced :-

\section{Anthropology.}

G. Fischer (Jena).-Die palaolithischen Funde von Taubach in den Museen zu Jena und Weimar, Dr. G. Eichhorn, illustrated. Hodder and Stoughton.-New Impressions of Primitive Man, E. Clodd; The British Race, J. Munro. Elliot Stock.-Folk Lore and Folk Stories of Wales, M. Trevelyan, with introduction by E. S. Hartland; Indian Folk Tales, E. M. Gordon (cheap edition).

\section{Biology.}

W. Engelmann (Leipzig).--Geschichte der biologischen Theorien, Prof. E. Radl, 2 Teil; Der Vegetation der Erde, xi. Band, Die Vegetationsverhältnisse der Balkanländer, Prof. L. Adamović, illustrated; xii. Band, Botanical Survey of the United States of North America, Prof. J. W Harshberger, illustrated; Prantls Lehrbuch der Botanik, new edition, illustrated; Vorträge und Aufsätze über Entwicklungsmechanik der Organismen, edited by Prof. W. Roux, vi. Heft, Über chemische Beeinflussung der Organismen durch einander, Prof. E. Küster; vii. Heft, Der Restitutionsreiz, Dr. H. Driesch. G. Fischer (Jena). -Recueil des Travaux botániques Néerlandais, publié par la Société botanique Néerlandaise, vol. iv., illustrated; Histologische Beiträge, Prof. E. Strasburger, Heft vii., illustrated; Zoologisches Wörterbuch, edited by Prof. H. E. Ziegler, Lief. iii. Hodder and Stoughton.-Germ Life:
Bacteria, H. W. Conn. T. Werner Laurie.-The Garden Booklets:- The Rose Garden; The Rock Garden; The Bulb Garden; The Formal Garden; The Water Garden; The Fern Garden. G. Philip and Son, Ltd.-School Gardening, W. E. Watkins and A. Sowman.

\section{Geography and Travel.}

Hodder and Stoughton.-Camps and Cruises of an Ornithologist, F. M. Chapman, illustrated; The Story of Geographical Discovery, J. Jacob. Hutchinson and Co.The American Egypt : a Record of a Sojourn in Yucatan and other Parts of Mexico, C. Arnold and F. J. Frost, illustrated. G. Philip and Son, Ltd.-A Guide to Geographical Books and Appliances, J. F. Unstead and N. E. MacMunn, edited by A. J. Herbertson; A Rational Geography, E. Young, part ii.; Our Own Islands, H. J. Mackinder; and a new edition of L'Estrange's Junior Course of Comparative Geography, revised and entirely rearranged, with maps in black and white.

\section{Geology.}

W. Engelmann (Leipzig).-Das Salz, dessen Vorkommen und Verwertung in sämtlichen Staaten der Erde, Dr. J. Buschman, 2 vols.

$$
\text { Mathematical and Physical Science. }
$$

W. Engelmann (Leipzig).-Tafeln für Maschinenrechnen, Prof. O. Lohse. Harper Brothers.-The Ether of Space, Sir Oliver J. Lodge, F.R.S. T. Werner Laurie.-Everyday Electricity, F. Broadbent, illustrated; Everyday Astronomy, H. P. Hollis, illustrated. T. Murby and Co.-Hobbs's Electrical Measurements (new edition). G. Philip and Son, Ltd.-Practical Elementary Science, T. Samuel and H. Foxcroft, three parts; A Handy Book of the Stars, Captain W. B. Whall (new edition). S. Rentell and Co., Ltd.-New editions of the Telegraphist's Guide: The Telegraphist's and Telephonist's Notebook; and Questions and Solutions in Telegraphy and Telephony: being Solutions to the Questions set by the City and Guitds of London Institute in the Ordinary Grades of Telegraphy and Telephony for the Years 1904-8, H. P. Few.

\section{Medrcal Science.}

W. Engelmann (Leipzig).-Die aphasischen Symptome und ihre corticale Lokalisation, Dr. N. von Mayendorf, illustrated; Die basedowsche Krankheit, Prof. H. Sattler, t Teil, Symptomatologie, illustrated; Anleitung zur Präparation und zum Studium der Anatomie des Gehirns, Dr. E. Villiger. G. Fischer (Jena).- - Handbuch der Anatomie des Menschen, Erster Band, Skeletlehre, illustrated; Ländliche Hygiene, Dr. E. Roth, Zwanzigster Band.

W. Engelmann (Leipzig).-Die Gasmaschinen, A. von Jhering, in 2 Teilen, 2 Teil, Geschichtliche Entwicklung und Beschreibung der Gasmaschinen, illustrated; Vorlesungen über Ingenieurwissenschaften, Prof. G. Mehrtens, I Teil, Statik der Baukonstruktionen und Festigkeitslehre, Erster Band, illustrated (new edition).

\section{Miscellaneous.}

W. Engelmann (Leipzig).-Die mnemischen Empfindungen in ihren Beziehungen zu den Originalempfindungen, Prof. R. Semon (Mneme, ii. Band). Hodder and Stoughton.- Thought and Feeling, F. Ryland.-The St. Bride's Press, Ltd.-Lectures on Sanitation, W. D. ScottMoncrieff; The Polar Planimeter: How it is Used and How it Operates, F. J. Gray.

\section{UNIVERSITY AND EDUCATIONAL INTELLIGENCE.}

Cambridge.-An exhibition of $5 \mathrm{ol}$. a year, tenable for two years, is offered by the governing body of Emmanuel College to an advanced student commencing residence at Cambridge as a member of Emmanuel College in October. The exhibition will be awarded at the beginning of October.

LonDon.-The governors of the Imperial College of Science have decided to purchase a section of freehold property in Cornwall giving free access to a mine for the 
practical study of surveying in connection. with the course in mining. Prof. E. W. McBride, F.R.S., of McGill University, Montreal, has been appointed chief assistant in the zoological department of the college. The title of "Professor Emeritus" has been conferred upon Prof. Tilden, F.R.S, in recognition of his long services as dean of the Royal College of Science and professor of chemistry.

M. Paul Langevin has been appointed professor of general and experimental physics at the Collège de France in succession to the late Prof. Mascart.

THE Scottish Meteorological Society offers for competition among matriculated students or graduates of the four Scottish universities, including University College, Dundee, a prize of $20 l$. for the best essay on a meteorological subject. As an indication of the kind of essay the council is prepared to consider, the following subject is mentioned :"A discussion of the extent to which the heat set free when water vapour is converted into the liquid state influences the temperature of the atmosphere, with special reference to the climatology of different parts of Scotland." An essay on any other subject will, however, be equally eligible. The essays must be lodged with the secretary to the Scottish Meteorologiral Society, 122 George Street, Edinburgh, on or before March 31, 1910.

Several further gifts to colleges and universities in the United States have bcen announced. Science states that at the recent commemoration of the founding of Johns Hopkins University, which opened thirty-three years ago, it was reported that the gift of Mr. Henry Phipps, of New York, for the psychiatric clinic was considerably in excess of $200,000 l$. A gift of $40,000 l$. to the University of Pennsylvania from an anonymous donor has been announced. The sons and daughters of the late Mr. and Mrs. F. C. A. Denkmann, of Rock Island, IIl., have promised to give a library building to Augustana College, Rock Island, the building to cost not less than 20,oool. By the will of Dr. Gordon W. Russell, of Hartford, Trinity College receives Ioool. for the natural history department and a collection of books on that subject.

THE Estimates for Civil Services for the year ending March 3I, 19I0, show an increase compared with the grants in the 1908 session. The provision made for universities and colleges shows an increase of $15,000 l$. for university education in Wales, and among increases under the heading "scientific institutions, \&c.," are $2000 l$. for the National Museum of Wales and 450ol. for the National Library of Wales. A building grant of $20,000 l$. is made in aid of the building fund of the University College, Bangor. The estimates for the Board of Education show an increase of $60,986 l$. The total estimates for the British Museum are $127,935 l$, and for the Natural -History Museum, South Kensington, 60,543l. It is interesting to notice under the estimates for the Board of Education an increase of $23,550 l$. available for grants for secondary schools and the instruction of pupil teachers, and of $20,000 l$. for grants for technical institutions and evening schools.

ON Friday evening, March 12, at the South-Western Polytechnic Institute, Chelsea, the certificates and prizes werc distributed by Dr. H. A. Miers, F.R.S., principal of London University. The principal of the polytechnic read a report which showed that the institute had been very successful in the university and other examinations. After the distribution Dr. Miers delivered an address. He said that twenty years ago he had taken a class in electricity at an evening recreative centre under the old School Board in Chelsea, and he felt on this account that his visit to Chelsea was particularly appropriate. His greatgrandfather, Francis Place, also had taken a leading part in founding some of the original polytechnics. He said that the great object of education should be to stimulate intellectual effort, and he knew no better way than by studies in science and art. In both it was always possible to discover or to produce something new, provided the student had the seeing eye. He himself had been led to researches and discoveries by chance observations. At a lecture at the Royal Institution one of his experiments on crystallisation had acted differently from his expectation, and this had led hin to a year's successful research. It was the seeing eye, educated by scientific study, which enabled discoveries to be made, and the more alert a student was the more likely he would be able to seize the opportunity when it came. Many discoveries had been made in this way, of which he gave examples. The interest of scientific and artistic studies was to him akin to the sporting instinct, which is merely a sense of expectation and curiosity of what was about to happen. All teachers should try to stimulate the spirit of research.

\section{SOCIETIES AND ACADEMIES. LONDON.}

Royal Society, January 14.- " On the Velocity of the Kathode Rays ejected by Substances exposed to the $\gamma$ Rays of Radium." By R. D. Kleeman. Communicated by Sir J. J. Thomson, F.R.S.

Part of the kathode radiation from a plate exposed to the $\gamma$ rays of radium consists of very soft rays which are absorbed in $1 \mathrm{~cm}$. or $2 \mathrm{~cm}$. of air.

The softness of the radiation is practically independent of the thickness of the radiator, and previous sifting of the $\gamma$ rays through a thick screen.

The radiation appears to be considerably softer on the side of the radiating plate where the $\gamma$ rays emerge than on the side'where they enter.

Measurements of the softness of the radiation for radiators of different materials on the side where the $\gamma$ rays entered showed that it is practically independent of the nature of the material of the radiator.

The soft radiation produced by the $\beta$ and $\gamma$ rays of radium together is of a more penetrating character than that produced by the $\gamma$ rays alone.

The penetrating kathode rays produced directly bv the $\gamma$ rays have been shown to possess different velocities. It was found that the penetrating power of the kathode radiation from a plate decreases with the increase of absorbability of the $\gamma$ radiation which produces it.

The velocity of these secondary rays as a whole is as a first approximation, equal to that of the $\beta$ rays of radium.

March 1r.-Sir Archibald Geikie, K.C.B., president, in the chair.-Note on the stability of Jacobi's ellipsoid: Sir G. H. Darwin.-The wave-lengths of lines in the secondary spectrum of hydrogen: H. E. Watson. A great deal of work has been done by numerous investigator: with the object of discovering the causes which produce two hydrogen spectra, the view for which there appears to be most evidence being that the primary spectrum arises from atomic hydrogen, and the secondary spectrum from molecular hydrogen. On the other hand, information as to the wave-lengths of the lines is very scanty, the only measurements of the red and yellow lines being those of Hasselberg about the year $188_{3}$. The results are based on Angstrom's scale, and were made with a prism spectroscope, so that they are not very trustworthy As it seemed highly important to have accurate information on the subject owing to the frequent necessity of eliminating hydrogen lines from a spectrum, the present work was undertaken. About 800 of the lines in the spectrum werc measured by means of a Rowland concave grating, the crror in the case of the stronger lines being probably not greater than 0.03 Angstrom unit. Many of the lines are very weak, and can barely be photographed even with prolonged exposures. No lines have been detected which are less refrangible than the $\mathrm{C}$ line, and very few appear to exist beyond the theoretical limit of the primary series according to Balmer's formula. In fact, of those which were seen in this position, the majority appear to be due to water-vapour, and it does not seem unlikely that the remaining ones are not due to hydrogen. A remarkable feature is an apparently continuous spectrum, which extends from the extreme ultra-violet almost to the visible region. A list is also given of the wave-lengths of thirtythree mercury lines which were seen in the spectrum, and measured with particular care in two orders. - The measurement of dielectric constants by the oscillations of ellipsoids and cylinders in a field of force: W. M. Thornton. The method used was to suspend by a quartz 